\title{
The Effects of Using Games on EFL Students' Speaking Performances
}

\author{
Pham Vu Phi Ho ${ }^{1}$, Nguyen Minh Thien ${ }^{2}$, Nguyen Thi My $\mathrm{An}^{3} \&$ Nguyen Ngoc Hoang Vy ${ }^{4}$ \\ ${ }^{1}$ Vice-president, Baria Vungtau University, Vung Tau City, Vietnam \\ ${ }^{2}$ Faculty of Foreign Languages, Dong Nai Technology University, Dong Nai province, Vietnam \\ ${ }^{3}$ Faculty of Foreign Languages, Tra Vinh University, Tra Vinh City, Vietnam \\ ${ }^{4}$ Faculty of Foreign Languages, Van Lang University, Ho Chi Minh City, Vietnam \\ Correspondence: Pham Vu Phi Ho, Baria Vungtau University, Vung Tau City, Vietnam. E-mail: \\ hopvp@bvu.edu.vn
}

\author{
Received: October 8, 2019 Accepted: October 29, 2019 Online Published: December 15, 2019 \\ doi:10.5539/ijel.v10n1p183 URL: https://doi.org/10.5539/ijel.v10n1p183
}

\begin{abstract}
This study investigated the effects of employing games on students' speaking performances in the classroom. 74 non-English major students, 36 students from the Tourism and Travel Management and 38 from the Office Management major from Tra Vinh University, participated in the study. The control group was trained with the methods of P-P-P (presentation, practice, and production) while the experimental group was trained with the same process but using selective games in the learning processes. Data collection was from the pre- vs. post-tests, questionnaire and interviews for analysis. The findings revealed that using games in the speaking classrooms, the students were motivated in the learning process and their speaking skills improve remarkably. The current study suggested teachers in the research context to apply gaming activities as an effective method to improve students' participation in the learning processes.
\end{abstract}

Keywords: game activities, speaking performance, accuracy, fluency, P-P-P (presentation, practice, and production)

\section{Introduction}

Teaching and learning English have been becoming extremely popular in Vietnam today. However, learning how to improve the speaking performance of EFL students is a problem for many learners of English, especially for non-English majors. According to Leong and Ahmadi (2017), speaking skills seem to be one of the hardest aspects of language learning, and many students feel difficult to express themselves in spoken English. The students did not dare to speak English in class for many reasons such as afraid of mistakes, lack of vocabulary and confidence. Though many students in Vietnam took many years to study English at schools, they cannot be able to practice English in real-life situations (Pham \& Nguyen, 2014). Meanwhile, students of non-English majors give a contribution to speaking learning problems. One of the main problems is the students' lack of awareness in learning speaking. They do not realize the need for English speaking in real life. They just learn English as their obligation since English becomes the final examination. In the research context, some students were good at English grammar, but their speaking abilities were not as expected. They are often too shy to even attempt to strike up a conversation. According to Pham and Nguyen (2019), teaching and learning speaking skills have not been primarily concerned by the teachers in Vietnam. The teachers favored their grammatical teaching to help their students gain high scores at schools. There still exist many difficulties in learning English in general and at Tra Vinh University in particular. These are some problems in teaching and learning speaking in classes. In the context of research, the students were not motivated to practice speaking in the classrooms. At the same time, the teachers were not employing appropriate methods to teach them how to speak English effectively. Particularly, the English subjects included in the curriculum of almost schools and universities. Students seem reluctant to learn English as a compulsory discipline in their colleges. In addition, the class size in Vietnamese classroom contexts is quite large and it is hard for the teacher to control the students (Pham, 2019). To many students, speaking skills are important to develop but challenging. In language teaching, games had proved that it was very important and it could create more opportunities to motivate students to practice English. 
Considering the role of speaking as one of the English language skills that non-English major students have to learn, we believe that an effort should be done to help students improve speaking performance. Pham and Do (2019) claim that teaching English activities in Vietnam today should place students as the central focus and the teachers are seen as facilitators who provide students creative contexts for language practices. Hence, using games is one of the ways to meet this issue. Gaming functioned as an effective instrument to help students practice the language. Games have some specialties. Students can learn in a fun way by using games. Teachers can use their creativity as wide as possible in using games. Gaming is a useful way to motivate students to practice their English (Wright, Betteridge, \& Buckby, 2006). In a sense, games are good tools to increase students' motivation to learn the English language. Particularly, the less proficient students had a chance to achieve their speaking abilities when they got involved in gaming (Hubbard, 1987).

In order to enhance students to speak in the classroom, teachers should choose an appropriate strategy in their teaching. In this research, the importance of using games as a strategy in the classroom that helps students to overcome their difficulties in speaking English. Particularly, for the practical significance, the body of literature and teaching resources provides the language teachers and learners a variety of games employed in all stages in speaking classrooms based on Objectives PET book (Louise \& Barbara, 2010). Figure 1 presents the conceptual framework for the current study.

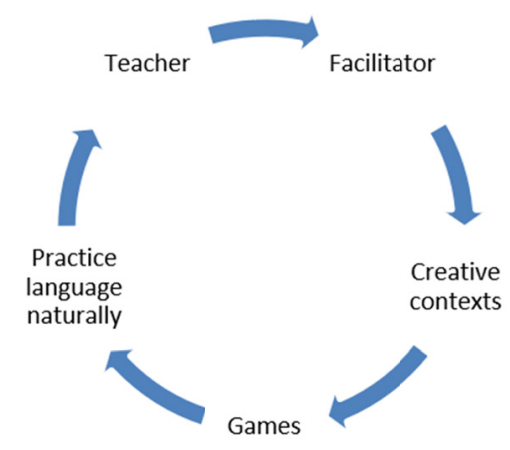

Figure 1. The conceptual framework for the current study

\section{Literature Reviews}

Speaking is an important skill for the students to interact with other people in the learning context as well as outside of the school. Through speaking, students could express themselves with concepts and ideas so that they could be triggered to acquire the new vocabulary and develop their uttering structure naturally (Nguyen \& Pham, 2018). Through speaking skills, the students could exchange their ideas with their peers and teacher to help them socialize themselves in society. As the students conducted their interaction, they could express their own ideas and clarify their own thinking. According to Nunan (1991), speaking is one of the skills that have to be mastered by students learning English. Speaking skills need to express effectively in terms of fluency and accuracy. Hybel (2001) stated that interaction or communicative skill is a process to share information, ideas, and feelings among people, and it also involves body language. Cameron (2001) says "speaking is the active use of language to express meanings so that other people could make sense of them". In other words, communicative skill is a good tool to express oneself's opinions and ideas and to make himself/herself understood by other people.

One of the best ways to encourage students to practice speaking in the classrooms was using games as a means of instruction (Nguyen \& Pham, 2018). Games motivated students to compete with one another in the competition so they could practice their speaking skills naturally. Games could be used as warming-up activities to introduce to a new lesson of learning or to review the previous learning content. Games can be used as a useful method to provide students opportunities to practice the English language with fun. Using games encouraged students to interact and communicate; students could learn how to express themselves to other people (Nguyen \& Pham, 2018). Also, gaming in the classroom had a great effect on training students on how to use the language because it was able to encourage students to interact with each other, work together and become more creative in expressing their ideas. Researchers have come up with different descriptions about the nature of games. Haycraft (1978) confirms that a game is an agreeable way of getting a class to use its initiative in English. Byrne (1995) and Hadfield (1990) defined games as a form of play and it was run with rules, but it should be 
enjoyable activities. Also, it was a way of getting the students to practice the language naturally.

Nguyen and Pham (2018) stated several reasons why games could be used in the speaking classroom to improve students' speaking skills. First, when employing games to teach the students how to play the games, the students might not be aware that they are practicing the language so they could do it naturally. Secondly, employing games in speaking classrooms is one of the ways to get students involved in communication. Furthermore, quiet students would have chances to participate in the learning activities actively to improve their English. Hence, games are frequently employed by the teachers to provide students chances to practice the language, to express their ideas and thought naturally during the competition. To this issue, the teachers should not only take advantage of using games for fun but also try to find ways to engage students in language learning.

The researchers considered the issue that there were many different kinds of games so the teachers need to be critically selective which games were appropriate to the levels and the ages of the learners so that the training was more successful (Harris, 2006), and which game met the purpose of the themes to train the students (MacKenty, 2006, p. 48). It is up to the types of games, genres of games that the teacher applied to train students in the classroom, it was beneficial to implement games as an active learning activity in the classroom. Several studies on the topic of games and speaking skills present results concerning students' improvement in speaking skills.

In the context of a Colombian public school, Urrutia and Vega (2006) conducted a study using games to help teenagers improve speaking skills through games. 20 girls and 20 boys from 14 to 18 years old participated in the study. The researchers implemented activities focused on oral games for promoting the development of students' speaking skill. Data collection was from the questionnaires, teacher's journals and video recordings. The researchers analyzed the data by using charts which included the percentages of students answers about the most difficult skill for them, how often they speak in English during the class and the factors that interfere at the time to speak, such as, shyness, lack of vocabulary, fear of humiliation, among others. The data collected suggest that speaking is the most difficult skill to develop, students usually present a lack of vocabulary, shyness, and fear of being humiliated; besides, the researchers explain that students show evidence about the importance of implementing games in the classroom for improving the speaking skills. However, the researchers found that the majority of the students did not speak English naturally during the class.

Similarly, Rama et al. (2007) investigated to see whether using language games was to improve speech skills during English classes at primary school called "Jurong" in Singapore. 78 students participated in the study. One group of students was trained with communicative methods while the other was used games to study. Data collection was from the pre-tests and post-tests. The finding indicated that games helped more than half of students improve communication in a second language. The students in the experimental group agreed that they were able to speak better and enjoyed game activities.

In another context, Salazar and Villamil (2012) attempted to investigate if using games helped enhance 4th graders speaking skills in Remigio Antonio Cañarte. The participants in this study were chosen randomly: Agustin (a1), Brayan (b2), Santiago (s3), and Kamila (k4). The researchers employed the observation method to examine the phenomena. Data collection was from field notes, checklist, and videotapes. The findings of this study show that using games is one of the fundamental tools to help the kids to use the language naturally. Games allow students to put in practice their speaking skills, and improve their listening skills. In other words, using games is a good method to trigger 4th graders to improve speaking skills and it is an interesting strategy to be implemented in an EFL classroom.

Leó and Cely (2010) also conducted a research study to enhance teenagers' speaking skills through games in a Colombian Public School. 40 students, 20 boys and 20 girls, participated in the study. The researchers used Video recordings, teacher's journal, and questionnaires to collect data. The findings of the study indicated that students felt at ease and confident when they produced oral tasks, particularly during game activities. However, the study just concentrated on encouraging students to speak confidently but did not mention methods to teach the students to enhance their fluency, pronunciation, and intonation.

Recently Pham and Nguyen (2019) conducted a study using peer-video-recording to help non-English majored students improve their speaking performances. 80 students from a university in Ho Chi Minh City, Vietnam, participated in the study. Both control and experimental groups were trained with the task-based approach, but only the experimental group was employed peer video recording methods. Data collection was from pre- vs. post-test and questionnaire surveys. The study found that the students in the experimental group enhanced their speaking performances remarkably compared to those students in the control group in terms of speaking fluency, pronunciation, and grammar. Most of the students felt favored with the use of peer-video-recording methods in the speaking classrooms to improve their speaking skills. 
Relating to the research context, the students do not have opportunities to speak English a lot during the speaking class, and the teachers failed to employ effective teaching methods to train the students how to use the language naturally, this paper aimed to seek for the responses whether using games is an effective way to help student improve their speaking ability.

\subsection{Research Questions}

1) Are there any effects of using games on students' speaking performances?

2) What are the students' attitudes towards using games in the speaking classes?

\section{Methodology}

\subsection{Setting \& Participants}

The research is conducted at Tra Vinh University. The school is located at No. 126, Nguyen Thien Thanh, National Highway 53, Ward 5, Tra Vinh city, Vietnam, where the administration center of the university is located. The study carried out with the second-year students of non-English majors. The researchers choose this level because the department of Foreign Language assigned to teach two classes of non-English majors.

At the set out of this study, two intact classes (74 students) of non-English majors aged from 18 to 22 at Tra Vinh University, participated in the study. Their majors vary in different fields like Tourism and Travel Management (36 students); Office Management (38 students). The Faculty of Foreign Language assign the researchers to teach two classes, so the samples of this research were two classes (Tourism and Travel Management; Office Management), consisted of 74 students who were chosen by using a convenience sampling method. The classes were not randomly assigned to experimental and control groups.

\subsection{Procedure}

The study was conducted the three phases of pre-training, while- and post-training, and training process. Two classes of non-English majors had an equal chance to be selected. Before the training, the students took the pre-tests of speaking tests. They had been trained with 13 sessions of Objective Pet book by the researcher/instructor. The students had a total of 90 periods (45mins. for each period, 23 class of meetings). In the Pre-training phase, before the intervention, all preparations were carefully made. First of all, 13 topics of speaking in the syllabus of the school were chosen to teach. Then, these topics were designed to teach the students in different ways, one for the control groups, using the P-P-P method, the other was for the experimental group, using games (See Table 1 below). All the 13 topics of speaking-lesson plans were conventionally designed in the same model of P-P-P (presentation, practice, and production). The researchers were creating an instructional design for each lesson (Harmer, 2007). Therefore, the lesson plans for the experimental group were using games activities in all three phases (Table 1). Then, the questionnaire was sent to the students, and the interviews were conducted to the students of the experimental groups. At the end of the course, the students took the post-test to measure students' speaking performances.

\subsection{Training Process}

The training procedures for the experimental and control groups took place within 12 weeks from the beginning of week 1 to the end of week 12. The three stages of presentation, practice, and production (P-P-P) of each treatment during 12 weeks were demonstrated in detail as follows. One difference in the treatment between the two groups was implementing games in the experimental group. 
Table 1. The three stages of presentation, practice, and production of the control group and experimental group

\begin{tabular}{|c|c|c|}
\hline & Control group & Experimental group \\
\hline Presentation & $\begin{array}{l}\text { - The topic and vocabulary were inductively } \\
\text { introduced to students through one of such contexts as } \\
\text { a short reading text, guessing, drawing and listening. } \\
\text { - Students were asked to deal with the short text tasks } \\
\text { individually or in pairs. } \\
\text { - Some prompting questions were posed by the teacher } \\
\text { so as to get students involved in the target structures } \\
\text { embedded in the text. } \\
\text { - Students were often asked to work in pairs to discuss } \\
\text { the guiding questions and then derive the grammar } \\
\text { rules with the teacher's facilitation. The teacher } \\
\text { explains the grammar rule or topic if necessary. }\end{array}$ & $\begin{array}{l}\text { - The topic and vocabulary were inductively introduced to } \\
\text { students through one of such contexts as a short reading text, } \\
\text { guessing, drawing and listening. } \\
\text { - Students were asked to deal with the text tasks individually or } \\
\text { in pairs. } \\
\text { - Some prompting questions were posed by the teacher so as to } \\
\text { get students involved in the target structures embedded in the } \\
\text { text. } \\
\text { - Students were often asked to work in pairs to discuss the } \\
\text { guiding questions and then derive the grammar rules with the } \\
\text { teacher's facilitation. The teacher explains the grammar rule } \\
\text { or topic if necessary. } \\
\text { - Before moving to the next stage of practice, the teacher } \\
\text { checked students' understanding by using games. } \\
\text { - Fast answer race games, sound games, word games, picture } \\
\text { games or caring and sharing games related to the topic lesson. }\end{array}$ \\
\hline Practice & $\begin{array}{l}\text { - The students were usually asked to work in pairs, } \\
\text { groups or individually to do communicative, reading } \\
\text { and listening tasks. }\end{array}$ & $\begin{array}{l}\text { - During this stage, the teacher using games through } \\
\text { communicative, reading and listening to help students get } \\
\text { involved in each task. }\end{array}$ \\
\hline Production & $\begin{array}{l}\text { - The students were asked to produce the structures } \\
\text { through some real-life situations, especially their own } \\
\text { real life. In this stage, working in pairs or groups was } \\
\text { often intensified; besides, the interaction between } \\
\text { individuals and the whole class was effectively } \\
\text { exploited. }\end{array}$ & $\begin{array}{l}\text { - The students were asked to produce the structures by } \\
\text { real-life situations, especially their own real-life through } \\
\text { games activities. } \\
\text { - Students wider opportunities to keep on participating in one } \\
\text { or two of such as speaking activities: caring and sharing } \\
\text { games, picture games, fast answer and race games, sound } \\
\text { games or word games. }\end{array}$ \\
\hline
\end{tabular}

\subsection{Scoring Rubrics}

The current study adapted the scoring rubrics from (Ur, 1997) to assess students speaking skills in terms of accuracy and fluency as follows.

Table 2. Criteria of assessment of speaking test

\begin{tabular}{lllc}
\hline Accuracy & Score & Fluency & Score \\
\hline $\begin{array}{l}\text { Little or no language produced. } \\
\begin{array}{l}\text { Poor vocabulary, a mistake in basic grammar, may have a } \\
\text { very strong foreign accent. }\end{array}\end{array}$ & 1 & $\begin{array}{l}\text { Little or no communication. } \\
\text { Very hesitant and brief utterances, sometimes }\end{array}$ & 2 \\
$\begin{array}{l}\text { Adequate but not rich vocabulary, occasional grammar slips, } \\
\text { slight foreign accent. }\end{array}$ & 3 & $\begin{array}{l}\text { difficult to understand. } \\
\text { Gets ideas across, but hesitantly and briefly. }\end{array}$ & 3 \\
$\begin{array}{l}\text { Good range of vocabulary, occasional grammar slips. } \\
\begin{array}{l}\text { Wide vocabulary appropriately used, virtually no grammar } \\
\text { mistakes. }\end{array}\end{array}$ & 5 & $\begin{array}{l}\text { Effective communication in short turns. } \\
\text { Easy and effective communication uses long } \\
\text { turns. }\end{array}$ & 5 \\
\hline
\end{tabular}

\subsection{Instrument}

\subsubsection{Interview}

In the current study, the interviews were used as supplemental data to support the answers obtained from the questionnaire. Interviews were usually conducted face-to-face by a researcher who orally asked questions to interviewees about certain pre-set questions (Punch, 1999) to explore people's experiences and their inner perceptions, attitudes, and feelings of reality. In this study, the researchers made use of the semi-structured interview. More questions are predetermined and there is sufficient flexibility to allow the interviewee an opportunity to shape the flow of information. The researchers purposefully select rich informants to explore in-depth data. Seven students were selected for the semi-structured interviews at the end of the course. The interviews took place in the classrooms when all other students were free from the learning sessions. The purpose was to make sure that all the interviewees felt at ease with the familiar environment to provide their answers as truly as possible. Audios were recorded by the smartphone with the permission of the interviewees 
for data transcripts. The students' names were coded as students' numbers in the class list such as student 15 , or student 21 . The purpose was to make sure that their names were confidential.

\subsubsection{Questionnaire}

Questionnaire data in the current study was explored to respond to the second research question. According to Wilkinson and Birmingham (2003), a good questionnaire is the one that enables the transmission of accurate answers of the respondents to the researcher. The questionnaire items need to be explicit and avoid ambiguous questions so that the respondents might interpret them as exactly as possible to provide effective data to the researcher. The current study employed the form of open- and ended-questionnaire (Brown, 2001), using 5-option Likerts' scale. Open-questionnaire helps the researchers clarify information that they cannot do in the ended questionnaire. Regarding the ended-questionnaire, in the term of participants, they can answer the questions with ease and the researcher can also get data easily. It helps to generate many specific questions into the research topic as well.

\subsubsection{Pre-Test vs. Post-Test}

In this study, the pre- test and post- test designs were the preferred method to compare the students' differences in terms of speaking skills after the treatments or interventions by using games. The researchers adopted the test of the Cambridge English Speaking Test Examination for both pre-test and post-test of the two groups. The purpose was to make sure that the students' speaking proficiencies were measured appropriately to the achieved levels after the interventions. The scoring rubrics were carefully assessed by the researchers (Table 2).

\subsection{Data Collection and Analysis}

At the end of the course, the researchers collected all the data from the semi- structured interview, questionnaire, and Pre- and Post-test of the students for evaluation. From the semi- structured interview, the interviews were asked for permission to record the interviews before each interview was held. Three days after the last topics, the interview was distributed to the experimental group to explore students' performance towards the intervention by using games. Each interview lasted about 10 minutes and was recorded by the smartphone. Then, they were transcribed by the researchers. After transcribing the data obtained from the interviews, the researchers categorized the themes of the data to support the answers to the second research question. Only related data were selected and presented in the current study. With regard to the questionnaire, the participants were asked to complete it at the end of the course within fifteen minutes. The questionnaire was designed with the five-point Likert's scale from 1 (strongly disagree) to 5 (strongly agree). Then it was analysed by SPSS vs. 22. Specifically, Independent and pair sample t-tests were run to investigate whether there were significant differences between students' pre- vs. post-test scores.

\section{Results/Findings \& Discussion}

\subsection{Students' Proficiency Levels}

Before the training sessions took place to both the control and the experimental group, the researchers administered the pre-tests to both groups to see if the students' speaking abilities were somehow similar. If yes, any difference occurred after the treatment would be attributed to the effects of the treatments. Table 3 presents the comparison of the pre-tests between the control and experimental group.

Table 3. Summary of pre-test results of the experimental (EG) and the control group (CG)

\begin{tabular}{lccccccc}
\hline & $\mathrm{N}$ & $\mathrm{M}$ & $\mathrm{SD}$ & $\mathrm{MD}$ & $t$ & $d f$ & $p$ \\
\hline Pre-tests & & & & & & & \\
Control group & 38 & 5.36 & .58 & -.02 & .04 & 72 & .96 \\
Experimental group & 36 & 5.38 & .68 & & & & \\
\hline
\end{tabular}

Note. *Independent sample t-test.

A descriptive statistic test was run to check the mean score between two groups in Pre- intervention period. The purpose of speaking tests was to measure students' speaking performances before and after the intervention. As can be seen from Table 3, the mean score of the students in the control group was $5.36(\mathrm{M}=5.36$; $\mathrm{SD}=.58)$. The mean difference was nearly 0 . At the same time, the mean score of the experimental group in the pre-test was 5.38 $(\mathrm{M}=5.38 ; \mathrm{SD}=.68)$. There seemed to be not different. The result of the independent t-test $(t(72)=.04 ; p=.96$, $p>.05)$ showed that there was no statistically significant difference between the control group and experimental group in the pre-tests. It indicates that the students' speaking proficiency before the treatment was equal. The null 
hypothesis was not rejected.

The following section presents the answers to the two research questions of the study.

\subsection{Research Question 1: Are There Any Effects of Using Games on Students' Speaking Performances?}

In order to respond to this research question, the quantitative approach to compare the scores between pre- test and post-test of the control group and the experimental group. In order to seek evidence for this effectiveness, Paired sample t-test was run to compare the mean scores between the pre- and post-test of the control group and experimental.

Table 4. Summary of pre- and post-test results of the control group

\begin{tabular}{lccccc}
\hline & $\mathrm{M}$ & $\mathrm{SD}$ & $t$ & $d f$ & $p$ \\
\hline Control group & & & & & \\
Pre-tests & 5.36 & .58 & -0.62 & 37 & 0.53 \\
Post-tests & 5.44 & .55 & & & \\
\hline
\end{tabular}

Note. *Paired sample t-test.

Table 4 compared the pre- vs. post-tests of the control group. As can be seen, on average, each student in the control group gained 5.36 score $(\mathrm{M}=5.36$; $\mathrm{SD}=.58)$, while they obtained $5.44(\mathrm{M}=5.44 ; \mathrm{SD}=.55)$ in the post-test. It seemed to state that the students improved a little more in the post-test compared to that of the pre-test (5.44 vs. 5.36). However, the results of the paired sample t-test $(t(37)=-.62 ; p=.53 ; p>.05)$ showed that there is no statistically significant difference between pre- vs. post-test of the control group. It indicates that the students' speaking proficiency in the control group did not remarkably improve after being trained with the P-P-P method. Table 5 presents the comparison of the experimental group between the pre- vs. post-test.

Table 5. Summary of pre- and post-test results of the experimental group

\begin{tabular}{llllll}
\hline & $\mathrm{M}$ & $\mathrm{SD}$ & $t$ & $d f$ & $p$ \\
\hline Experimental group & & & & & \\
Pre-tests & 5.38 & .68 & -7.53 & 35 & .00 \\
Post-tests & 6.55 & 1.02 & & & \\
\hline
\end{tabular}

Note. *Paired sample t-test.

Table 5 reveals the comparison between the pre- vs. post-tests of the experimental group. As can be seen, on average, each student obtained a mean score of $5.38(\mathrm{M}=5.38 ; \mathrm{SD}=.68)$ in the pre-test. However, each of them, on average, gained 6.55 score $(\mathrm{M}=6.55 ; \mathrm{SD}=1.02)$ in the post-test. There seemed to see that the mean score of the students in the post-test was higher than that in the pre-test. The results of the paired sample t-test $(t(35)=-7.53 ; p$ $=.00 ; p<.05)$ illustrated that there was a statistically significant difference between the pre- vs. post-test of the experimental group. The null hypothesis was rejected. It indicates that the students' speaking proficiency improve significantly after the treatment. In other words, using games in the speaking classroom had great effects on students' English speaking performances.

As presented above, before the treatment, the students' speaking performances (Table 5) were not different. In other words, the students' speaking proficiencies before the study were similar. In case, there was any difference in speaking performances between these two groups, we could draw a conclusion for the effects of the intervention. Table 6 presents the comparison of the post-tests between the control and the experimental group.

Table 6. Comparison of the post-tests between the control and experimental group

\begin{tabular}{|c|c|c|c|c|c|c|}
\hline & $\mathrm{M}$ & $\mathrm{SD}$ & $\mathrm{MD}$ & $t$ & $d f$ & $p$ \\
\hline Post-tests & & & & & & \\
\hline Control group & 5.44 & .55 & -1.10 & -5.81 & 72 & .00 \\
\hline Experimental group & 6.55 & 1.02 & & & & \\
\hline
\end{tabular}

Table 6 illustrates the comparison of the post-tests between the control and experimental group. As can be seen, on average, each student in the control group gained a 5.44 score in the post-test $(\mathrm{M}=5.44 ; \mathrm{SD}=.55)$. However, 
each student in the experimental group after the training of using games, on average, gained a 6.55 score in the post-test $(\mathrm{M}=6.55 ; \mathrm{SD}=1.02)$. The mean difference between these two groups was -1.10 . In addition, the results of the independent sample t-test $(t(72)=-5.81 ; p=.00 ; p<.05)$ reveals that there was a statistically significant difference between the experimental group and control group performed in the post-tests. That is, the students in the experimental group improved their speaking skills outweighed the students in the control group. The null hypothesis was rejected. The finding of the current study confirmed the effects of using games in the classroom in order to get the students involved in the learning activities and to help them practice the language more naturally.

In brief, the first research question sought to find out whether games have any effect on the speaking skills of EFL students in the sample at Tra Vinh University. The findings of the current study revealed that before the treatment, there was no significant difference between the control and experimental group in speaking performances. However, after using games in the speaking classroom to help students engaged in the learning activities and practice the language, the students in the experimental group improved their speaking skills remarkably, whereas the students of the control group who learned speaking skills with the method of P-P-P was not statistically improved their speaking skills. Therefore, the current study concluded the effects of the games on the students' speaking performances. This finding corresponded to Rama et al. (2007) that games showed significant difference scores between the pre- and post-test that games allow more than half of students to improve communication in a second language vocabulary. Along similar lines, the finding of Salazar and Villamil (2012), supports the implementation of games for speaking skill, games can be used to motivate students to practice the language. That is, the students were provided opportunities to interact with one another in the classrooms when using games as a means for language training. The finding of the current study contradicted that of Urrutia and Vega's (2006) when they found their students sometimes spoke English, but the majority of the students did not speak during the English class. The study signifies the possibility of implementing using games at Tra Vinh University and using games have positive effects on EFL students' speaking performance in the classroom.

\subsection{Research Question 2: What Are the Students' Attitudes Towards Using Games in the Speaking Classes?}

In order to respond to this research question, the survey questionnaire was distributed among them after they had received the treatment. The evaluation was rated on a narrow three-bank scale as follows: low evaluation (1-2.8), medium evaluation (2.9-3.6), and high evaluation (3.7-5.0). Data from semi-structured interviews were also presented to support the survey data.

Table 7. Students' attitudes towards task design

\begin{tabular}{llll}
\hline Item & Contents & M & S.D. \\
\hline 1 & I like teachers use games in the classroom. & 4.14 & 0.67 \\
2 & The contents of the game are suited to the lesson. & 4 & 0.53 \\
3 & Topic lessons of games activities are relevant to my daily life in this course. & 4.16 & 0.6 \\
4 & The teacher makes the subject matter of this course seem important. & 4.02 & 0.55 \\
5 & Students' interest in speaking after being thought about using games. & 4.14 & 0.12 \\
6 & The ease of students in giving and responding expressions after being thought of using games. & 4.03 & 0.76 \\
7 & Students' motivation to get used to speak English and to study harder. & 4.11 & 0.57 \\
\hline
\end{tabular}

As can be seen from Table 7, the mean scores ranged from 4.00 to 4.16 showed that the students had positive attitudes towards the task designs. A majority of the participants found the speaking topic lessons of games activities are relevant to daily life in this course $(M=4.16)$, it can be seen that the authentic games help students found interests in their study, they see the role of meaningful learning and they can study by themselves. Learning through games activities help to provide scientific knowledge in addition to practicing and learning the target language. Students almost agreed that the ways of teacher teaching variety and content of the lessons were designed at reasonable; they are interested in speaking English $(\mathrm{M}=4.14)$ and increase curiosity stimulated during the lesson $(\mathrm{M}=4.11)$. In addition, the teacher makes the subject matter of this course seem important ( $\mathrm{M}$ $=4.02$ ) that engage student learning English.

Combining with semi-structured interviews, it can be concluded that students believed that games from the teacher help them reduce boredom and concentrate more on their learning. At first, the students were not comfortable with the learning activities. They did not know exactly what they were expected to do. When the researchers asked students about the effects of using games in the speaking classroom, some of them said that 
"the games provided us the open atmosphere and helped us to express ourselves more" (Students 15, 17). "Gaming is a fun thing so when we play, we learn how to express our ideas naturally" (Students 21, 27). "Yes, because we integrate each other by thinking in the game, we forget the shyness and we pay more attention in class" (Student 35). "I am more confident to participate in playing games with my peers. At the end of the class, I felt excited to continue participating in gaming activities" (Students 24, 32).

From the interview result above, the researchers concluded that students have high motivation in learning English through using games; high confidence and they were not nervous, they felt happy and fun by using guessing game techniques in the speaking class. Most of the students said it was fun because studying the English applying game was interesting. This finding is consistent with Huyen and Nga's (2003) study that students obtained positive attitudes in the ways that games could help them to learn vocabulary. Students were able to learn more new words and they could apply those words in a relaxed and comfortable environment. Students got the motivation to speak English; the students had opportunities to interact among the class.

Combining with field notes through the teaching process, the researchers took notes on what was seen in each class of meeting to support the research questions. At first, the students seemed confused and shy when they were requested to speak. They felt hard in expressing their ideas, opinion, and thoughts, and they were still hard to pronounce the new vocabulary and also less motivated to play the games. However, when the teacher used games in the speaking classrooms, the atmosphere was different. The students could learn how to talk confidently; they are excited and participate in the activity. They speak out the words, correctly and incorrectly but at least, they have chances to think about what they learn during games. The results in this study support the findings of Rama et al. (2007) who found that learners enjoyed more games activities. In this regard, it must be noted that games could increase the students' motivation and enthusiast with strength students and even weak students. After analyzing the results from interviews, questionnaire, and the tests, the study claimed the effect of using games on students' speaking performances and the students' attitudes towards using games on the speaking classes.

As presented above, the current study confirmed the effects of using games in English classrooms to enhance students' speaking performances. The results of post-test indicated that there was a significant difference in the mean score of the experimental and control group in which the mean of the experimental group outweighed the mean of the control group $(\mathrm{M}=6.55$ vs. $\mathrm{M}=5.44)$. In other words, using games as a means to teach students how to speak in English was more effective than the other method. It also indicates that there is a significant difference between the students in experimental classes and control classes. Thus, the game is an effective media to improve students' speaking skill context. Therefore, the advantages of using games are proven. It can encourage students' speaking confidence, develop students' speaking fluency, and encourage the group in developing a short conversation or daily life.

Besides, based on interviews, the researchers found out that the importance of using games in the English learning process. Games are motivating and exciting experiences for students to develop speaking skills in a fun and comfortable way. Students were motivated in the learning processes and actively participated in the games. When using the language to take part in the games, the students found more comfortable with language learning and they could use it in a friendly way. It is also supported by previous research findings such as Lia's (2015) who found that the implementation of games in the speaking classroom enabled the students to became more confident in speaking skills and they become more active in the learning processes. The findings of the current study set lights to the teachers who attempted to develop their students' speaking performances at the research contexts.

\section{Conclusions}

The findings of the current study indicated that the null hypothesis of the first research question was rejected. The employment of games was a good way to be implemented in the speaking classrooms. Besides, the students expressed their positive attitudes towards this kind of activity to be motivated in the learning processes. The students engaged actively in the learning processes and they learned how to speak English better through games in the classroom. Moreover, the students were more motivated in showing their speaking performances; games could make the students more confidence to perform in front of the class. Briefly, the current findings show that using games in the speaking classroom was beneficial to the students in speaking performance; it did appeal to the students' interests in speaking topics within the context of EFL students at Tra Vinh University.

In addition to the effects of using games to improve students' speaking performances, the current study had 
some limitations. First, this study was conducted in one university and the sample was not selected randomly. Therefore, it would not be generalized to other contexts. Second, the length of the training was not long enough to confirm the effects of games on all other aspects. There should be further research to consider these issues. Also, this study did not consider the length of using games and the number of games using in each training section. Though the implementation of games in the speaking classrooms was not new, the current study provided another consideration to the teachers in the research context to take this activity into account when they encountered difficulties in their teaching methods.

\section{References}

Brown, J. D. (2001). Using Survey in Language Program. Cambridge: Cambridge University Press.

Buzanni, D. (2008). The Use of Guessing Games in Improving Students' Speaking Ability at the Second Year Students of MTS IkhtiyarulUmmahPamekasan. Malang: Institute of Teacher Training and Education Budi Utom.

Byrne, D. (1995). Teaching Oral English. Harlow: Longman Group UK.

Cameron, L. (2001). Teaching languages to young learners. Cambridge: Cambridge University Press. https://doi.org/10.1017/CBO9780511733109

Dwiyanti, S. (2009). The improvement students' Speaking skill through guessing games technique. Jakarta: English Department School of teacher training and education Kusuma Negara. Retrieved May 15, 2018, from

http://www.scribd.com/doc/22057958/the-improvement-ofstudent\%e2\%80\%99s-speaking-skill-through-gu essinggames-technique

Hadfield, J. (1990). Intermediate Communication Games. Hong Kong: Thomus and Nelson and Nelson and Sons Ltd.

Harmer, J. (2007). The practice of English language teaching (3rd ed.). Essex, Pearson: Longman.

Harris, C. (2006). Meet the New School Board: Board games are back-and they're exactly what your curriculum needs. School Library Journal, 55(1), 24-26.

Haycraft, J. (1978). An introduction to English language teaching. Harlow: Longman.

Herliani, N. (2013). The use of guessing game to improve student's speaking skill. Research proposal. Indonesia University of Education.

Hubbard, J. (1987). A Training Course for ELT. Oxford: Oxford University Press.

Huyen, N. T. T., \& Nga, K. T. T. (2003). Learning vocabulary through games. Asian EFL Journal. Retrieved May 25, 2018, from http://www.asian-efl-journal.com/dec_03_vn.pdf

Hybel, D. (2001). Understanding speaking interaction. New York: Cambridge University Press.

León, W. U., \& Cely, E. V. (2010). Encouraging Teenagers to Improve Speaking Skills through Games in a Colombian Public School. Colombia: Universidad Nacional de Colombia.

Leong, L. M., \& Ahmadi, S. M. (2017). An Analysis of Factors Influencing Learners' English-Speaking Skill. International Journal of Research in English Education, 2(1), 34-41. https://doi.org/10.18869/acadpub.ijree.2.1.34

Lia, A. (2015). Improving students' speaking skills through speaking board games of grade VIII of SMP N 13 Yogyakarta. Unpublished Undergraduate Thesis.

Louise, H., \& Barbara, T. (2010). Objective PET. Cambridge University Press.

MacKenty, B. (2006). All Play and No Work. School Library Journal, 52(2), 46-48.

Nguyen, T. M. A., \& Pham, V. P. H. (2018). Improving EFL Students' Speaking Performance by Using Games in the Classroom (pp. 128-137). Conference Proceedings, ISBN: 978-604-922-659-5.

Nunan, D. (1991). Language Teaching Methodology. UK: Prentice Hall International.

Pham, V. P. H. (2019). The Effects of Lecturer's Model e-comments on Graduate Students' Peer e-comments and Writing Revision. Computer Assisted Language Learning, In press. https://doi.org/10.1080/09588221.2019.1609521

Pham, V. P. H., \& Do, T. P. T. (2019). High School Students' Common Errors in Writing Essays. International Journal of English Linguistics, 9(6), 309-319. https://doi.org/10.5539/ijel.v9n6p309 
Pham, V. P. H., \& Nguyen, T. B. (2014). The Effects of Communicative Grammar Teaching on Students' Achievement of Grammatical Knowledge and Oral Production. English Language Teaching, 7(6), 74-86. https://doi.org/10.5539/elt.v7n6p74

Pham, V. P. H., \& Nguyen, T. T. H. (2019). The Effects of Peer-video Recording on students' Speaking Performance. International Journal of English Linguistics, 9(4), 178-191, https://doi.org/10.5539/ijel.v9n4p178

Punch, F. K. (1999). Introduction to Social Research-Quantitative and Qualitative Approaches. London: SAGE Publication IC.

Rama, J., Ying, C. C., Lee, K. R., \& Luei, A. Y. (2007). Using games to improve speech skills. Retrieved October 10, 2019, from http://citeseerx.ist.psu.edu/viewdoc/download?doi=10.1.1.535.1334\&rep=rep1\&type=pdf

Salazar, C., \& Villamil, A. (2012). Application of games for the development of speaking skill in fourth graders from remigio antonio cañarte school. Universidad Tecnologica de Pereira, Colombia.

Urrutia, R., \& Vega, T. (2010). Encouraging Teenagers to Improve Speaking Skills through Games in a Colombian Public School. Boston.

Wilkinson, D., \& Birmingham, P. (2003). Using Research Instruments - A Guide for Researcher. London: Routledge. https://doi.org/10.4324/9780203422991

Wright, A., Betteridge, D., \& Buckby, M. (2006). Games for language learning. Cambridge: Cambridge University Press. https://doi.org/10.1017/CBO9780511667145

\section{Copyrights}

Copyright for this article is retained by the author, with first publication rights granted to the journal.

This is an open-access article distributed under the terms and conditions of the Creative Commons Attribution license (http://creativecommons.org/licenses/by/4.0/). 